\title{
FEATURE
}

\section{ALA Committee on Professional Ethics}

\author{
Scott P. Muir (muir@rowan@edu), Associate Provost, Library information \\ Services, Rowan University. Muir has been a librarian since 1978 and was former- \\ ly active in the Special Libraries Association and has been active in the American \\ Library Association since 1987. He is currently a member of COPE. \\ Sara Dallas (sdall las@sals.edu), Director, Southern Adirondack Library System. \\ Dallas serves as chair of COPE and is an American Library Association councilor \\ at large. She served on the Public Library Association board and has been active \\ in many ALA and PLA committees.
}

\section{What is COPE and Why Does lt Exist?}

The Committee on Professional Ethics (COPE) is an American Library Association (ALA) Council Committee. COPE's charge is to augment the ALA Code of Ethics by explanatory interpretations and additional statements, prepared by the committee or elicited from other units of ALA. When units of the Association develop statements dealing with ethical issues, a copy is sent to the Committee on Professional Ethics for review so that it may be compared to the existing ALA Code of Ethics in order to determine whether or not conflicts are present. COPE then offers non-binding opinions on issues before the ALA Council.

The Council on Committees appoints the seven members of COPE. In addition, ALA Divisions are asked to recommend a liaison to meet with COPE and to share areas of concerns from the Division and the field, as well as report back to the Divisions on the work of the committee. The COPE liaisons offer a much richer process for engaging in discussion on ideas in the formal meetings.

\section{What is the Code of Ethics?}

The Committee on Professional Ethics has also been charged with reviewing the ALA Code of Professional Ethics which can be found on their website.

The Code of Ethics, initially adopted in 1939, is intended to be a set of guiding principles for how librarians and library staff conduct themselves in their interactions with library users, with their colleagues, and in the provision of excellent service. These guidelines are not prescriptive and neither this committee nor ALA has the power to censure any librarian who does not follow the guidelines. Other library organizations such as the Special Libraries Association and the Medical Library Association have similar codes of ethics.

\section{What Does the Committee Do?}

The committee meets at ALA Annual and ALA Midwinter to discuss items of business, develop programming, and prepare a report each year for ALA Council. COPE conducts some business electronically throughout the year. 


\section{COPE - FeAture $₫$}

COPE members are also asked to serve on various ALA working groups. One of major activities of the committee is to develop a program for ALA Annual.

COPE continuously looks for ways to raise awareness of potential ethical dilemmas in the field. The 2016 ALA Annual program was "No Room at the Library." The committee decided the format "What Would You Do?" created an opportunity help people think about real-life situations, before they might occur in their work setting.

Nine committee members acted in three short skits highlighting scenarios that might occur in libraries. The scenarios focused on religious insensitivity toward a Muslim employee by a patron, a complaint about a transgender person using a restroom, and a group planning to use library meeting room space that wanted to limit participation in their meeting only to people of a certain race. Each skit ended with the question, "what would you do?" The purpose of the program was to present provocative situations for consideration. The scenarios and discussions were not intended to state that there was a specific right answer to any of these situations, but instead to help the audience consider how they would want to respond to these situations if and when they happened in their library. Each scenario was followed by comments and opinions from the audience.

The panel included Loida Garcia-Febo, who served both as moderator and who set the tone of the program by giving an overview of ethics. Loida is well known for her work with international human rights, advocacy and access to information, and in working with diverse populations. She is President of Information New Wave, a not-for-profit, seeking to bring education to multiethnic populations. Garcia-Febo is a member of the ALA Executive Board and the IFLA Governing Board. She was instrumental in developing the IFLA's Code of Ethics for Librarians and other Information Workers. Also serving on the panel were Jeffrey Sowder, Anastasia Chiu, and Sara Ahmed. The program room was packed with nearly 125 people, with many standing in the back. Attendees interactively engaged with the panel, each other, and the COPE members. The audience members offered their ideas and concerns, with some sharing the difficulties they face in their local environments. This program format has been well received in the past and COPE plans to repeat it again. COPE is now considering potential scenarios for the 2017 Conference in Chicago.

\section{The Future}

Another way the committee is looking to raise ethical awareness is through a survey developed by past COPE Chair, Martin Garnar (see p. 6). The survey investigated how professional ethics are taught in LIS programs, with results being reported in this issue of the Journal of Intellectual Freedom and Privacy. Other awareness efforts include the possibility of developing an ethics toolkit and communicating with the ALA divisions and round tables to improve communication and understanding regarding the role of COPE. 